\title{
Behandling av hjerneslag
}

Behandlingen av hjerneslag har endret seg stort de siste 25 årene, bl.a. med etableringen av egne slagenheter (1). I dette nummer av Tidsskriftet presenteres to viktige artikler om henholdsvis hjerneblødning og hjerneinfarkt. Hole \& Kloster har beregnet insidensen av førstegangs hjerneblødning i en stor prospektiv studie i Vestfold fylke (2). De fant en årlig insidens på 20,5 per 100000 personer i perioden 2010-14, noe som er lavere enn resultatene i en studie fra Innherred kommune i Trøndelag i perioden 1994-96 (3), men høyere enn i en studie fra Sørlandet i perioden 2005-09 (4). Som ved andre studier ble det funnet høy mortalitet, idet nesten $40 \%$ av pasientene døde innen 30 dager. For mange som overlever, er derimot prognosen god. Omtrent halvparten kom tilbake til egen bolig og trengte ikke tilsyn eller ekstra hjelp. Nesten en firedel av pasientene brukte warfarin, oftest på grunn av atrieflimmer. Bruken av warfarin er nå synkende etter at såkalte NOAK-midler (nye perorale antikoagulasjonmidler) ble godkjent for tromboseprofylakse. NOAK-behandling er assosiert med mindre risiko for hjerneblødning enn behandling med warfarin, og vi kan derfor forvente en nedgang i insidensen av hjerneblødning $\mathrm{i}$ årene som kommer.

Som Hole \& Kloster påpeker, behandles de fleste pasienter med hjerneblødning konservativt, og prognosen har ikke endret seg vesentlig på mange år. Det trengs derfor mer forskning for å bedre den akutte behandlingen av hjerneblødning. Med unntak av store lillehjerneblødninger har randomiserte kontrollerte studier ikke vist at nevrokirurgisk behandling bedrer prognosen. Slike studier har heller ikke vist at hemostatisk behandling bedrer prognosen. Det pågår nå en landsomfattende randomisert kontrollert studie, NOR-ICH-studien, ledet fra Bergen, der traneksamsyre eller placebo gis til pasienter med akutt hjerneblødning innen tre timer etter symptomstart. Flere studier tyder på at blodtrykkssenkning kan bedre prognosen ved akutt hjerneblødning (5).

For behandling av akutt hjerneinfarkt har det derimot skjedd store fremskritt de siste årene. Først ble intravenøs trombolytisk behandling innen tre timer etter symptomstart tatt i bruk, og tidsvinduet er senere forlenget til 4,5 timer (6). De siste ti årene er trombektomi med mekanisk fjerning av blodpropper i store intrakranielle pulsårer i økende grad blitt tatt i bruk. Den første randomiserte studien som viste at trombektomi er effektiv behandling hos pasienter med kjent symptomstart, ble publisert i 2014, og i 2015 ble det publisert ytterligere fire studier som viste at trombektomi bedrer det funksjonelle resultat etter 90 dager (7). Mange sykehus tilbyr trombolytisk behandling eller trombektomi til pasienter som våkner eller blir funnet med akutt hjerneinfarkt, dersom det foreligger normal FLAIR MR, men patologisk diffusjonsvektet MR.

For både trombolytisk behandling og trombektomi gjelder at jo raskere behandlingen kan gis etter symptomstart, desto større er sjansen for et godt resultat. De senere årene har det derfor vært arbeidet godt i norske sykehus for å bedre logistikken, blant annet ved å opprette slagteam, fra pasienten ankommer i akuttmottaket og til det blir gitt trombolytisk behandling eller utført trombektomi. Alle pasienter må til CT- eller MR-undersøkelse først for å utelukke hjerneblødning. For mange pasienter er nå den såkalte dør-til-nål-tiden under ti minutter. Fordi vurderingene må skje raskt er det alltid en risiko for å gi trombolytisk behandling til pasienter som ikke har akutt hjerneinfarkt. All erfaring tilsier nå at trombolytisk behandling til slike pasienter innebærer svært liten risiko for alvorlige blødninger (8).
Prehospital forsinkelse er den viktigste årsaken til at pasienter med akutt hjerneslag kommer for sent til sykehus. Faiz og medarbeidere publiserer en viktig studie av faktorer som forlenger den prehospitale fasen (9). De fant at transporten til sykehus tar lenger tid når pasienten henvender seg til fastlegekontor eller legevakt enn når pasienten henvender seg til AMK-sentralen, der nesten alle blir transportert videre med ambulanse - mot under halvparten av dem som henvender seg til fastlegekontor eller legevakt. De konkluderer med at allmennleger bør få bedre opplæring i rask håndtering av pasienter med akutt hjerneslag. Det må også satses mer på opplysningskampanjer hvor befolkningen lærer mer om enkle symptomer på akutt hjerneslag, og at AMK-sentralen må kontaktes så raskt som mulig ved symptomer på hjerneslag. Tidligere opplysningskampanjer har vært effektive, men effekten har bare vart noen måneder. Denne typen opplysningskampanjer må derfor gjentas med jevne mellomrom.

På landsbasis får i dag ca. 15 \% av pasientene med akutt hjerneinfarkt intravenøs trombolytisk behandling, og ved noen sykehus er andelen over $25 \%$ (10). For en del pasienter er tidspunktet for symptomstart ukjent, og for disse er intravenøs trombolytisk behandling ofte ikke indisert. Dersom prehospital forsinkelse kunne reduseres til et minimum ved nye opplysningskampanjer, er det grunn til å tro at så mange som halvparten av dem som kan ha nytte av det, kan få intravenøs trombolytisk behandling i tide. Det er et viktig og oppnåelig mål.

\section{Halvor Næss}

halvor.ness@helse-bergen.no

Halvor Næss (f. 1957) er overlege ved Nevrologisk avdeling, Haukeland universitetssykehus og professor ved Universitetet i Bergen.

Forfatter har fylt ut ICMJE-skjemaet og oppgir ingen interessekonflikter.

\section{Litteratur}

1. Indredavik B, Bakke F, Solberg R et al. Benefit of a stroke unit: a randomized controlled trial. Stroke 1991: 22: 1026-31.

2. Hole BJ, Kloster R. Spontane intracerebrale blødninger i Vestfold. Tidsskr Nor Legeforen 2017; 137: 793.

3. Ellekjaer H, Holmen J, Indredavik B et al. Epidemiology of stroke in Innherred, Norway, 1994 to 1996. Incidence and 30-day case-fatality rate. Stroke 1997; 28 $2180-4$.

4. Tveiten A, Ljøstad U, Mygland A et al. Intracerebral hemorrhage in southern Norway-a hospital-based incidence study. Eur Neurol 2012; 67: 240-5

5. Steiner T, Al-Shahi Salman R, Beer R et al. European Stroke Organisation (ESO) guidelines for the management of spontaneous intracerebral hemorrhage. Int J Stroke 2014: 9: 840-55.

6. Hacke W, Kaste M, Bluhmki E et al. Thrombolysis with alteplase 3 to 4.5 hours after acute ischemic stroke. N Engl J Med 2008; 359: 1317-29.

7. Wahlgren N, Moreira T, Michel P et al. Mechanical thrombectomy in acute ischemic stroke: Consensus statement by ESO-Karolinska Stroke Update 2014/ 2015, supported by ESO, ESMINT, ESNR and EAN. Int J Stroke 2016; 11: 134-47.

8. Chernyshev OY, Martin-Schild S, Albright KC et al. Safety of tPA in stroke mimics and neuroimaging-negative cerebral ischemia. Neurology 2010; 74: 1340-5.

9. Faiz K, Sundseth A, Thommessen B et al. Prehospitalt forløp ved akutt hjerneslag. Tidsskr Nor Legeforen 2017; 137: 798.

10. Norsk Hjerneslagregister. 2015. Trombolyse: https://www.kvalitetsregistre.no/ registers/353/resultater/627 (16.5.2017) 